\title{
Postfire Vegetation Dynamics in Three Rangelands of Northeastern Patagonia, Argentina
}

\author{
César M. Rostagno, ${ }^{1}$ Guillermo E. Defossé, ${ }^{2}$ and Héctor F. del Valle ${ }^{1}$ \\ Authors are ${ }^{1}$ Research Scientists, Centro Nacional Patagónico (CONICET), Blvd Brown s/n, (9120) Puerto Madryn, Chubut, \\ Argentina; and ${ }^{2}$ Research Scientist and Director, Centro de Investigación y Extensión Forestal Andino Patagónico \\ (CIEFAP-CONICET), Route 259 km 4, (9200) Esquel, Chubut, Argentina.
}

\begin{abstract}
In many rangeland ecosystems, the role of fire on vegetation dynamics has been the object of detailed studies. In Argentina, and especially in Patagonia, the knowledge of how fire changes vegetation is scarce. In 3 areas affected by wildfires on different dates (in 1988, 1994, and 1998), we determined the structure of the vegetation (plant cover, density, and biomass) and compared it with that of nearby unburned areas. Based upon these data, we present a qualitative state-and-transition model of this rangeland. For the sites burned in 1988 and 1994, aerial biomass, density, and cover of perennial grasses were significantly greater $(P \leq 0.05)$ for burned than for unburned areas. For the site burned in 1998 , although there were no significant differences in perennial grass biomass and cover, density was significantly greater compared to the unburned area. Total shrub cover was significantly lower $(P \leq 0.05)$ in burned than in the unburned areas, attaining $49.7 \%, 15.0 \%$, and $5.5 \%$ of that of the unburned areas for the sites burned in 1988, 1994, and 1998, respectively. Similar to cover, density for most shrubby species was significantly greater in the unburned than in the burned areas for the 3 sites. Grazing and fires of different intensities, combined with variable rainfall, makes the prediction of postfire vegetation changes difficult. However, it can be generalized that fire changed the vegetation from shrub-dominated steppes, a persistent state in northeastern Patagonia, into a grass-dominated transient state. This change has persisted for more than 10 years after a fire event. From the perspective of sheep raising, the significant postfire increase in perennial grass biomass represents a substantial improvement in the condition of these rangelands. However, repeated fires would be necessary to control the sprouting shrubs and maintain the grass-dominated state.
\end{abstract}

\section{Resumen}

En muchos pastizales naturales del mundo, el papel del fuego en la dinámica de la vegetación ha sido objeto de estudios detallados desde hace un largo tiempo. En Argentina, especialmente en Patagonia, el conocimiento del rol de fuego como factor modelador de la vegetación es escaso. Nosotros determinamos la estructura de la vegetación (cobertura, densidad y biomasa) en tres áreas quemadas accidentalmente en diferentes años (1988, 1994 y 1998) y la comparamos con áreas adyacentes, no quemadas. Basados en esta información presentamos un modelo cualitativo de estados-y-transiciones. Para los sitios quemados en 1998 y 1994, tanto la biomasa aérea como la densidad y cobertura de los pastos perennes fueron significativamente $(\mathrm{P} \leq$ 0.05) mayores respecto a las áreas no quemadas. Por el contrario, la cobertura total de arbustos, al igual que la densidad de la mayoría de las especies registradas, fue significativamente $(\mathrm{P} \leq 0.05)$ menor en las áreas quemadas que en las no quemadas, alcanzando el $49,7 \%, 15,0 \%$ y 5,5\% del total de cobertura arbustiva de las áreas no quemadas para los fuegos ocurridos en los años 1988, 1994 y 1998, respectivamente. La incidencia de distintas historias de uso y fuegos de distinta intensidad, combinado con una alta variabilidad de las lluvias, dificultan el pronóstico de los cambios en la vegetación posterior a los incendios. Sin embargo, podemos concluir que el fuego transformó la estepa arbustiva, un estado persistente, dominante en los tres sitios estudiados, en estepas herbáceas con arbustos, las cuales representarían estados transitorios. Estos cambios en la estructura de la vegetación se han mantenido por mas de 10 años. Desde la perspectiva de la producción ovina, el incremento significativo en la biomasa de pastos perennes y la disminución de arbustos no forrajeros representan una mejora importante en la condición de los pastizales. De todas maneras, la persistencia del estado dominado por pastos perennes dependerá en gran medida de la ocurrencia de nuevos incendios que favorezcan el control de los arbustos en las áreas recientemente quemadas.

Key Words: Monte region, rangeland fires, shrub control, perennial grasses biomass, state-and-transition model

\section{INTRODUCTION}

Shrub encroachment has been recognized as one of the most important ecological and economic problems in semiarid rangelands. This encroachment, typically caused by unpalat-

Research was funded in part by a grant from CONICET, Argentina (PIA-CONICET 6387/97)

Correspondence: César M. Rostagno, Centro Nacional Patagónico (CONICET), Blvd Brown s/n, (9200) Puerto Madryn, Chubut, Argentina. E-mail: rostagno@cenpat.edu.ar

Manuscript received 22 January 2005; manuscript accepted 22 December 2005. able shrubs, can affect rangeland biodiversity and threatens the sustainability of subsistence and commercial livestock grazing. Although the proximate causes for woody plant displacement of perennial grasses are the subject of debate (Archer et al. 1995; Scholes and Archer 1997), land use practices such as 
heavy grazing and reductions in fire frequency have often been implicated (Mc Pherson 1995; Van Auken 2000).

Numerous examples indicate that once established, shrubs can dominate a site for very long periods, even under grazing exclusion (Smith and Schmutz 1975; West et al. 1984). Thus, the dominance of woody plants in previously grass-dominated communities generally represents stable states that resist changes in livestock grazing management (Laycok 1991). Under these conditions the concept of alternative stable states, as described in the state-and-transition model (Westoby et al. 1989) can be relevant to understanding the dynamics of these rangelands (Van Langevelde et al. 2003; Briske et al. 2005) and to apply this knowledge for management purposes (Bestelmeyer et al. 2004).

In many rangelands affected by woody plant encroachment, the role of fire in vegetation dynamics has been the object of detailed studies. Most of these studies showed that, in the first successional stages after a fire event, the reduction of biomass of shrubs and other tree-like species is associated with a relative increase in biomass of grasses and grass-like species (Hodgkinson and Harrington 1985; West and Hassan 1985; Wambolt and Payne 1986; Pfeiffer and Steuter 1994; Bóo et al. 1996). However, fire does not always alter plant community composition (Owens et al. 2002) or when it is altered and shrub cover is reduced, it has not always resulted in anticipated increases of herbaceous production (Wambolt et al. 2001).

In Argentina, and especially in its Patagonian region, knowledge of the effects of fire on vegetation is limited (Rodriguez and Cwielong 1992). In the central portion of the Monte Region, fire contributed to the conversion of shrublands into communities with a more favorable balance between woody and herbaceous species. In this region, a summer wildfire increased herbaceous biomass by a factor of 3 (Guevara et al. 2001). In the southern portion of the Monte region, in northeastern Patagonia, there is evidence that fire played an important role in vegetation dynamics (Dentoni et al. 2001). In the book "Diario de Viaje de Exploración al Chubut 1865-1866" (Diary of Exploration Trip to Chubut 18651866), Claraz (1988) described his journey through this region, indicating that various zones had been affected by fires and that aboriginals frequently burned these rangelands for hunting or communication purposes.

The defeat of the aboriginals in 1879 and the subsequent European colonization brought many changes in the use of these rangelands. Fires were suppressed, and sheep were introduced for wool and meat production (Soriano 1983). This grazing activity, carried out continuously up to the mid1980s, drastically changed the structure and dynamics of these rangelands (Ares et al. 1990). As a result, palatable grasses declined and nonpalatable shrubs increased (Beeskow et al. 1995; Parizek et al. 2002). Prescribed burning was not applied by ranchers or encouraged by natural resources institutions to control unwanted woody plants. During the last 20 years, sheep production has declined in Patagonia because of low prices and rangeland deterioration. Declining sheep production or cessation of grazing in many ranches along the coast has resulted in an increase in both grass and shrub biomass. This biomass, and especially its high proportion of fine fuels, constitutes a highly flammable fuel. During the dry summer season, high temperatures, coupled with low relative humidity and moderate to strong winds, increase the risk of a fire occurrence, ignited either by lightning or man (Dentoni et al. 2001).

As a consequence, the frequency of fire occurrence has increased. Fire effects from 1988 to the present suggest that after a fire, there is an increase in perennial grasses and a decrease in shrubs. Although this trend has been confirmed for other similar rangeland areas, it has not been studied in the Monte region of Patagonia in Argentina. Studying 3 areas burned on different dates, the objectives were therefore 1) to determine the structure of the vegetation and its comparison with that of nearby unburned areas and 2) to describe, based upon the structure and vegetation dynamics of burned and unburned plots, the potential alternative vegetation states and the transitions between the states of these rangelands. The results should help us to understand the role of fire in these ecosystems and also to explore the possibility of using prescribed fire as a management tool to improve forage production on these rangeland areas.

\section{MATERIALS AND METHODS}

\section{Study Area}

The study area is located in the southern portion of the Monte phytogeographical province (Soriano 1950) in the northeastern part of Chubut province in Patagonia, Argentina, and is centered at approximately lat $42^{\circ} 50^{\prime} \mathrm{S}$ and long $65^{\circ} 00^{\prime} \mathrm{W}$. Within this area, and based upon Landsat TM satellite images, we selected 3 areas burned by wildfire. The first area was burned in late spring (mid-November of 1988, site 1), the second area in early summer (January 1994; site 2), and the third one in midspring (October 1998; site 3). Site 1 is located about $20 \mathrm{~km}$ to the southeast of the city of Puerto Madryn (Alsúa Ranch) and sites 2 and 3 (Gallastegui Ranch) are 12 and $8 \mathrm{~km}$ to the west of the same city. We chose 1 unburned area adjacent to each of the burned ones as reference, against which to make the comparisons. We regarded each burned site as a population and each quadrat or transect as a sample from that population. Variation from transect to transect or quadrat to quadrat then provided an estimated variation inherent in the population (Wester 1992).

Average annual precipitation (1979-1999) in the 3 sites is approximately $236 \mathrm{~mm}$ (data from the weather station located in the Centro Nacional Patagónico [CENPAT], Puerto Madryn); mean annual temperature is $13.5^{\circ} \mathrm{C}$. The sites are located at about $100 \mathrm{~m}$ above sea level, in a flank pediment with a SW-NE slope. Soils are Xeric Haplocalcids, about $50 \mathrm{~cm}$ deep, taking as their lower limits the Patagonian Gravel formation (Rostagno and del Valle 1988). The vegetation of the 3 sites is a shrub-grass steppe, and is composed by 3 strata. In site 1, dominant species in the upper stratum is molle (Schinus johnstonii Bark.); quilembai (Chuquiraga avellanedae Lorentz) and mata mora (Nardophyllum chiliotrichioides [Remy] A. Gray) are the dominant species in the intermediate stratum and flechilla (Stipa tenuis Phil.) in the lower (herbaceous) stratum. In sites 2 and 3, the upper stratum (1.2 to $2.5 \mathrm{~m}$ tall) is composed of the shrubs jarilla (Larrea divaricata Cav.) and molle. Uña de gato (Chuquiraga hystrix Don.) is also present in the upper stratum of site 2 . The intermediate stratum ( 0.5 to $1.2 \mathrm{~m}$ tall) is mainly composed by yaoyín (Lycium chilense Miers ex Bertero) and quilembai, 


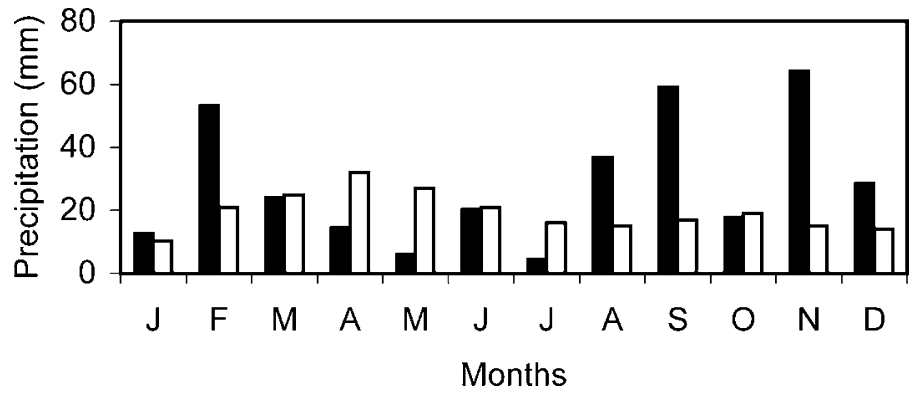

Figure 1. Long-term (1979-1999) monthly precipitation ( $\square$ ) and precipitation recorded in $1999(\mathbf{\square})$ in the CENPAT Weather Station, located in Puerto Madryn, Chubut, Argentina.

whereas the lower stratum ( 0 to $0.5 \mathrm{~m}$ tall) is dominated by grass species such as flechilla, coirón amargo (Stipa speciosa Trinius et Ruprecht), and coirón poa (Poa ligularis Nees ap. Steudel).

All 3 sites had been grazed by sheep since the beginning of the 20th century and up to about 20 years ago. Since then, sites 2 and 3 have been excluded from sheep grazing; site 1 was excluded from sheep grazing for 1 year after the fire and then year-round grazing was resumed.

\section{Assessment of Aerial Biomass, Cover, and Density of Herbaceous Species}

Aerial biomass of herbaceous species was assessed at the end of the growing season (peak standing crop) at the beginning of December 1999, approximately 11 years, 6 years, and 1 year after fire occurrence for sites 1,2 , and 3, respectively. Aerial biomass was determined in 10 plots of $1 \mathrm{~m}^{2}(0.5 \mathrm{~m} \times 2 \mathrm{~m})$ randomly located in the burned and in nearby unburned areas of the 3 sites ( $<100 \mathrm{~m}$ distant for sites 1 and 3 , and $500 \mathrm{~m}$ for site 2 ). Biomass was harvested at ground level, taken to the lab and separated into forbs and the different grass species, oven-dried for 48 hours to constant weight, and weighed. Prior to the harvest, grass cover and density were determined in each of the $1-\mathrm{m}^{2}$ plots. Grass cover was visually estimated by a trained operator using a quadrat with painted markings to aid in cover estimations. The number of individuals for each plant species was counted in each plot. The density of pasto hilo (P. lanuginosa Poiret at Lamarck), a rhizomatous species, was not considered because of the difficulty of recognizing individual plants.

\section{Cover and Density of Shrub Species}

Canopy cover (line-intercept) was determined along 10 transects, each $50 \mathrm{~m}$ long, and density of shrub species was determined in 10 plots measuring $2 \mathrm{~m} \times 50 \mathrm{~m}\left(100 \mathrm{~m}^{2}\right)$.

\section{Statistical Analyses}

Vegetation measurements in burned and unburned treatments were analyzed in each site by independent Student's $t$ tests using the SPSS software (SPSS 1997).

\section{RESULTS}

\section{Rainfall During 1999}

Total rainfall recorded during 1999 was $342.3 \mathrm{~mm}, 50 \%$ above the long-term average (Fig. 1). The average long-term monthly

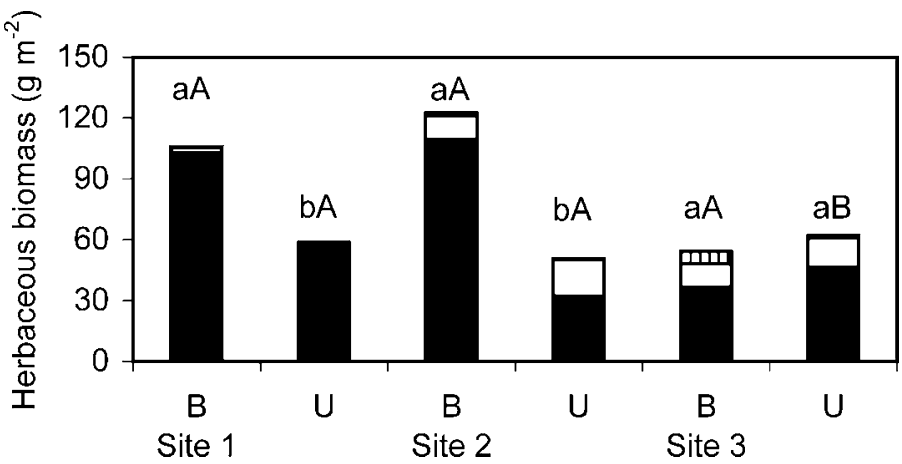

Figure 2. Standing perennial grasses (Stipa tenuis [ $[\mathbf{\square}$ and other perennial grasses $[\square]$ ) and dicot biomass [ $\square$ ] in the burned (B) and unburned $(U)$ areas of the 3 study sites in the southern portion of the Monte region, Chubut, Argentina. Within a site, means with different letters (lowercases for total grasses and uppercases for dicots) are significantly different at $P \leq 0.05$.

precipitation and its distribution for 1999 were recorded at the weather station located in Puerto Madryn, less than $20 \mathrm{~km}$ from the 3 study sites. During the spring, the main growing season for the perennial grasses, precipitation was abundant, with September and November well above their long-term averages.

\section{Aerial Biomass of Perennial Grasses and Forbs}

For the sampling sites burned in 1988 and 1994 (sites 1 and 2, respectively), aerial biomass of grass species was significantly greater $(P \leq 0.05)$ for the burned than for the unburned (control) areas (Fig. 2); at site 3, burned in 1998, there was no significant difference in grass biomass. Stipa tenuis was the dominant grass species in the 3 sites. At site $1, S$. tenuis accounted for $>95 \%$ of the biomass of total perennial grasses, in both burned and unburned areas, whereas at sites 2 and 3 the subdominant grasses, P. ligularis, P. lanuginosa and S. speciosa, accounted for $25 \%$ to $35 \%$ of the total perennial grass biomass in the unburned areas and $11 \%$ to $23 \%$ in the burned areas. Poa lanuginosa contributed to perennial grass biomass and cover mainly in the burned areas of sites 2 and 3, where it colonized the mounds originally occupied by shrubs, and the transient microdunes formed after the fire. Forb biomass was the lowest of total herbaceous biomass. For sites 1 and 2, forbs represented approximately $1 \%$ of herbaceous biomass; at site 3 it increased from $2 \%$ in the unburned area to $11 \%$ in the burned area.

\section{Density and Cover of Perennial Grasses}

Density and cover of perennial grasses were significantly greater $(P \leq 0.05)$ in the burned than in the control areas of sites 1 and 2 . At site 3 , density of perennial grasses was also significantly greater in the burned compared to the unburned area, but no difference in cover was found (Fig. 3).

\section{Shrub Cover}

Total shrub cover was significantly greater $(P \leq 0.05)$ in the unburned than in the burned areas for all 3 sites (Fig. 4). The total shrub cover in the burned areas attained $49.7 \%, 15.0 \%$, and $5.5 \%$ of the total shrub cover of the unburned areas for sites 1,2 , and 3 , respectively. In the unburned areas of the 


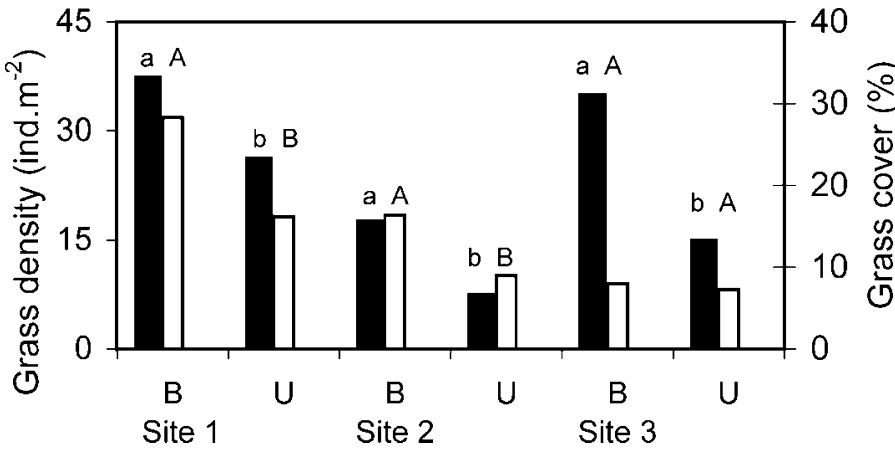

Figure 3. Density ( $\square$ ) and cover $(\square)$ of perennial grasses in the burned $(B)$ and unburned $(U)$ areas for the 3 study sites in the southern portion of the Monte region, Chubut, Argentina. Within a site, means with different letters are significantly different at $P \leq 0.05$.

3 sites, C. avellanedae was the dominant species (Table 1), representing $36.4 \%, 61.9 \%$, and $62.7 \%$ of the total shrub canopy cover for sites 1,2 , and 3, respectively. Subdominant species were different at each site. At site 1 , where shrub cover was about $60 \%$ of the shrub cover of sites 2 and 3, and more evenly distributed among different species, N. chiliotrichioides was the subdominant species and represented the $27.8 \%$ of the total shrub cover. At sites 2 and 3, L. divaricata and $P$. globosum were the subdominant species and represented the $15.8 \%$ and $21.7 \%$ of the total shrub cover, respectively. In the burned area of site 1, 11 years after the fire occurrence, $C$. avellanedae attained a cover equivalent to the $53 \%$ of its original cover (unburned area), whereas at site 2 (6 years postfire) and site 3 ( 1 year postfire) its cover represented $<1 \%$, and $0 \%$ of the cover found in the unburned area. Cover of the subdominant species in the burned areas was low, compared to the unburned areas, with the exception of $S$. johnstonii, which had greater cover in the burned than in the unburned areas at sites 1 and 2 (Table 1 ).

\section{Shrub Density}

Similar to plant cover, shrub density was, in general, significantly greater in the unburned area for the 3 sites. The exceptions were S. johnstonii, and C. avellanedae for site 1 ,

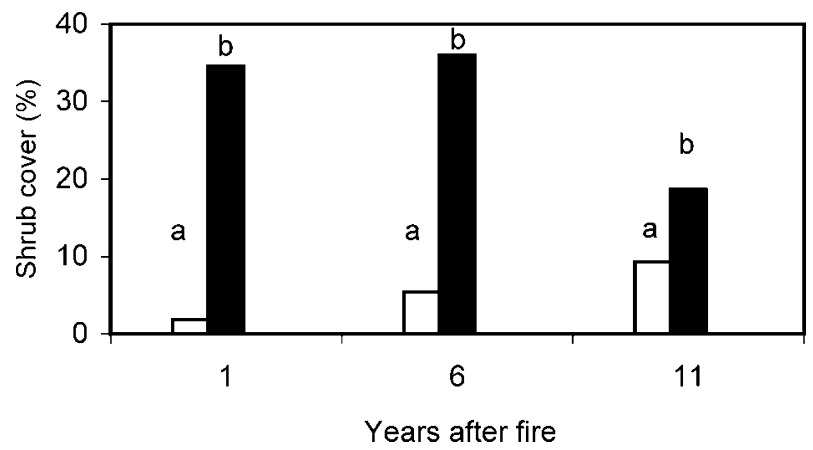

Figure 4. Total shrub canopy cover for the burned $(\square)$ and unburned (ם) areas for sites 1, 2, and 3, sampled 11, 6, and 1 years, respectively, after a fire in the southern portion of the Monte region, Chubut, Argentina. Within a site, means with different letters are significantly different at $P \leq 0.05$.
Table 1. Average shrub canopy cover for the unburned areas and the areas burned in 1988 (site 1), 1994 (site 2), and 1998 (Site 3) in the southern portion of the Monte region, Chubut, Argentina, as sampled in December 1999.

\begin{tabular}{|c|c|c|c|c|c|c|}
\hline \multirow[b]{2}{*}{ Plant species } & \multicolumn{2}{|c|}{ Site 1} & \multicolumn{2}{|c|}{ Site 2} & \multicolumn{2}{|c|}{ Site 3} \\
\hline & \multicolumn{2}{|c|}{ Unburned Burned } & \multicolumn{2}{|c|}{ Unburned Burned } & \multicolumn{2}{|c|}{ Unburned Burned } \\
\hline & --------- & - & \% & & & \\
\hline Chuquiraga avellanedae & $6.8^{*}$ & 3.6 & $22.3 * * *$ & 0.2 & $21.7 * \star *$ & 0.0 \\
\hline \multicolumn{7}{|l|}{ Nardophyllum } \\
\hline chiliotrichioides & $5.2 * \star \star$ & 0.2 & NA & NA & NA & NA \\
\hline Larrea divaricata & NA & NA & $5.7 * \star \star$ & 1.1 & $1.7^{\star}$ & 0.5 \\
\hline Larrea nitida & NA & NA & $0.1 * \star$ & 0.0 & $0.0 \mathrm{NS}$ & 0.0 \\
\hline \multicolumn{7}{|l|}{ Prosopidastrum } \\
\hline globosum & $2.8 \mathrm{NS}$ & 2.1 & $4.3 * \star \star$ & 1.6 & $7.5^{\star \star \star *}$ & 0.9 \\
\hline Chuquiraga hystrix & $3.2 * *$ & 0.3 & $1.1 * *$ & 0.4 & NA & NA \\
\hline Schinus johnstonii & $0.4 * *$ & 2.7 & $0.2 * *$ & 1.9 & $2.2^{\star}$ & 0.5 \\
\hline Junelia ligustrina & $0.1 * * *$ & 0.0 & $1.8^{* * *}$ & 0.1 & $0.9 * *$ & 0.0 \\
\hline Lycium chilense & $0.2 \mathrm{NS}$ & 0.4 & $0.6 * *$ & 0.1 & $0.6 * \star *$ & 0.0 \\
\hline
\end{tabular}

${ }^{*}, * *, * \star *$ Within a site, and for the burned and unburned conditions, species mean cover were significantly different at $P<0.05, P<0.01$, and $P<0.001$, respectively. NA indicates not applicable; NS, not significant.

and P. globosum for sites 2 and 3, in which density was greater in burned than in unburned areas (Table 2). Schinus johnstonii and $P$. globosum, both species of intermediate to low forage value, form large individuals with the lower branches remaining prostrate. After fire, individuals of $S$. johnstonii and $P$. globosum sprout from sediment-covered branches and generate several separate, though not distinct, individuals. This may, in part, explain why there were more individuals of $S$. johnstonii in the burned areas of site 1 and more P. globosum at sites 2 and 3. For the burned areas of these sites, the density of $L$. divaricata, the subdominant species, was $29.3 \%$ and $40.0 \%$ with respect to the unburned areas.

Table 2. Average shrub density for the unburned areas and the areas burned in 1988 (Site 1), 1994 (Site 2), and 1998 (Site 3) in the southern portion of the Monte region, Chubut, Argentina, as sampled in December 1999.

\begin{tabular}{|c|c|c|c|c|c|c|}
\hline \multirow[b]{2}{*}{ Plant species } & \multicolumn{2}{|c|}{ Site 1} & \multicolumn{2}{|c|}{ Site 2} & \multicolumn{2}{|l|}{ Site 3} \\
\hline & \multicolumn{4}{|c|}{ Unburned Burned Unburned Burned } & Unburned & Burned \\
\hline & \multicolumn{6}{|c|}{ 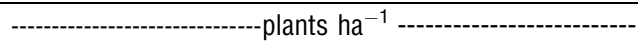 } \\
\hline Chuquiraga avellanedae & $1300 \mathrm{NS}$ & 1320 & $2960 * * *$ & 180 & $2950 * \star \star$ & 0 \\
\hline \multicolumn{7}{|c|}{ Nardophyllum } \\
\hline chiliotrichioides & 1040 * * & 300 & NA & NA & NA & NA \\
\hline Larrea divaricata & NA & NA & $1670 * * *$ & 480 & $1050 * *$ & 420 \\
\hline Larrea nitida & NA & NA & $100 \mathrm{NS}$ & 80 & $90 *$ & 0 \\
\hline \multicolumn{7}{|l|}{ Prosopidastrum } \\
\hline globosum & $420 *$ & 220 & $120 * *$ & 420 & $350 \mathrm{NS}$ & 550 \\
\hline Chuquiraga hystrix & $1300 * * *$ & 200 & $650 * \star *$ & 140 & NA & NA \\
\hline Schinus johnstonii & 120 * & 340 & $40 \mathrm{NS}$ & 40 & $250 \mathrm{NS}$ & 125 \\
\hline Junelia ligustrina & $280 * * *$ & 20 & $300 \mathrm{NS}$ & 180 & $325^{\star \star *}$ & 50 \\
\hline Lycium chilense & $400 *$ & 160 & $680 *$ & 300 & $570 * * *$ & 70 \\
\hline
\end{tabular}

, ${ }^{* *},{ }^{* * *}$ Within a site, and for the burned and unburned conditions, species mean cover were significantly different at $P<0.05, P<0.01$, and $P<0.001$, respectively. NA indicates not applicable; NS, not significant. 
The recovery of Lycium chilense and Junelia ligustrina, the 2 shrub species with the highest forage value (Elissalde et al. 2002), was not severely limited by fire and presented, 1 year after the fire, densities equivalent to $12 \%$ and $15 \%$ with respect to the unburned area. At site 2, burned 6 years prior to sampling, these species attained a density in the burned areas of $44 \%$ and $60 \%$ with respect to the unburned area, whereas at site 1 , their densities were $40 \%$ and $7 \%$ in the burned areas with respect to the unburned ones. Nardophyllum chiliotrichioides, a species of intermediate forage value, subdominant at site 1 , seems to be less tolerant to fire than does $C$. avellanedade, the dominant species, and recovered more slowly after fire, attaining, in the burned area, $30 \%$ of its density as compared to the unburned area.

\section{DISCUSSION}

\section{Perennial Grasses}

Fire drastically altered plant community composition at all 3 sites, changing the vegetation from shrub-dominated steppes, the dominant physiognomy in northeastern Patagonia, to grassdominated steppes. Though fires and postfire environmental conditions differed between sites, the biomass, cover, and density of perennial grasses increased markedly in the burned areas, especially at sites 1 and 2 . The lower grass biomass found at site 1 , burned 11 years previous to sampling, with respect to site 2 , burned 6 years before sampling, could be attributed to the effects of grazing. However, the cover of grasses in both the burned and unburned areas of site 1 was greater than at site 2 . Individuals of $S$. tenuis at site 1 were smaller than at sites 2 and 3 , and presented a lower biomass:cover ratio. Although herbaceous biomass and cover in the burned and unburned areas were similar at site 3 , burned 1 year before sampling, plant density was much greater in the burned area. Stipa tenuis seedlings accounted for this high difference. In the control areas, $S$. tenuis dominated the shrub interspaces characterized by a soil with low nitrogen and phosphorous content (Rostagno et al. 1991). Burning not only releases nutrients and reduces shrub competition (Cook et al. 1994) but also releases spaces previously occupied by shrubs. Thus, in the burned areas, perennial grasses, mainly $S$. tenuis and $P$. lanuginosa, readily colonize the mounds that represent the most fertile patches in these ecosystems. In a controlled experiment dealing with the emergence and survival of $S$. tenuis in poor and rich resource microsites, Bisigato and Bertiller (1999) found that the addition of inorganic $\mathrm{N}$ increased seedling emergence and plant biomass. According to these authors, emergence and growth of S. tenuis may be promoted during humid years by an increased concentration of inorganic N. Thus, the protection from grazing and above average long-term rainfall during the spring after the fire may have favored the recovery of the burned areas. In the Caldenal ecosystem in south-central Argentina, Bóo et al. (1996) also found that 1 year postfire, the original cover values of $S$. tenuis tended to be re-established. The sustained increase in cover values of $S$. tenuis after the burns was in part attributed to fire tolerance. This conclusion was later experimentally supported by Peláez et al. (2003), who found that the relative growth rates in tillers of burned plants of $S$. tenuis were greater than in tillers of unburned plants.

\section{Shrub Cover and Density}

The degree to which plant community composition returned to prefire levels can be evaluated by comparing shrub cover and density. Though shrub cover may better represent the amount of resources shrubs may capture in a given area during a given period (i.e., space, water, and nutrients), density represents the potential plant community that can be expected as shrubs attain maturity. For example, the plant physiognomy of the burned area of site 1 , where total shrub cover was only $9.3 \%$, could be considered a grass steppe with scattered shrubs (Ares et al. 1990). Nevertheless, in the short term this community will probably recover the prefire physiognomy, though not the composition, because C. avellanedae attained the same density as in the unburned area. The postfire community composition in each site will in part be determined by the relative fire resistance among species, given mainly by their abilities to sprout following a fire (Bóo et al. 1997). Except for C. avellanedae, the woody species most severely affected at site 3 , the other species presented high sprouting rates. At this site, burned 1 year before sampling, the sprouting rates of $L$. divaricata and S. johnstonii were $40 \%$ and $50 \%$, respectively. Willard (1973) and Bóo et al. (1997) observed similar sprouting rates for $L$. divaricata 1 year after the exposure to a summer wildfire in the wetter portion of the Monte phytogeographical province $(45 \%)$ and the southern Caldenal $(40 \%)$. However, the sprouting rate for S. johnstonii in the Willard's study (Willard 1973) was only $18 \%$. In the burned areas of the present study, S. johnstonii as well as P. globosum sprouted from several branches buried beneath wind-blown sediment or fossorial rodent mounds; 1 individual may produce several separated sprouts that were considered as different individuals in the density sampling. Indeed, the density of $S$. johnstonii in the burned area of site 1 and P. globosum in sites 2 and 3 were greater than in their respective unburned areas.

\section{Persistent Alternative States}

In northeastern Patagonia, the shrub-dominated steppes seem to represent stable communities, probably favored by the relative long ( $>100$-year) history of continuous sheep grazing. These communities are relatively self-maintaining and the removal of livestock grazing did not change shrub dominance. However, livestock removal in sites 2 and 3 favored the recovery of grasses to provide sufficient biomass and a continuity of fine fuel above a threshold value for fire to spread. This view is consistent with the interpretation of thresholds on the basis of modifications of the disturbance regime (Peterson et al. 1998). For grass steppes, grazing would determine, via a reduction of fine fuel, the rate at which fire thresholds are surpassed (Briske et al. 2003). At site 1 grazing did not reduce fuel load sufficiently to prevent fire spread. At the time of the sampling, grass cover was much greater in the unburned area of site 1 than in the unburned areas of sites 2 and 3 (Fig. 3). Under these conditions, fire would represent a potential disturbance that triggers the transition from the shrub-dominated state to a grass-dominated state as it is described in the state-andtransition model (see Fig. 5).

The persistence of the state dominated by perennial grasses will depend on the recovery rate of the dominant woody species. Indeed, the postfire recovery rate of dominant shrubs 


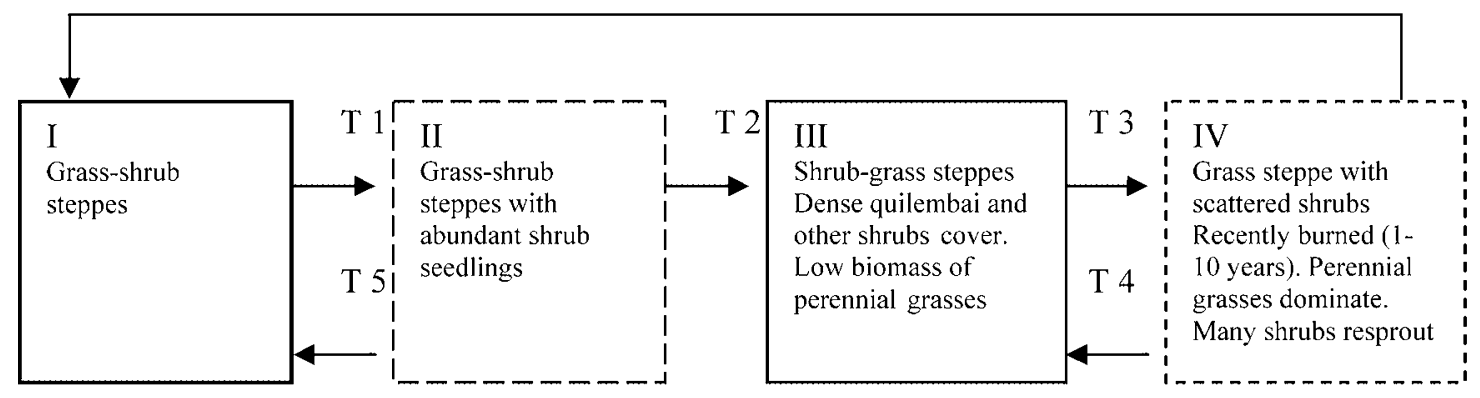

State I: It was probably the dominant community before the introduction of sheep grazing. To the east of site $1(20-30 \mathrm{~km})$, with an average annual rainfall $10-15 \%$ higher than in the study sites, large tracks of grass steppes with scattered shrubs are common.

State II: A transient State, similar to State I, plus abundant shrub seedlings. It may change into State I or III. State III: Shrubs, mainly quilembai, dominate in this State; perennial grasses occupy the intershrub spaces. Mounds associated to shrubs allow deeper water percolation in the soil profile and favors species with deeper root systems (i.e. quilembai and jarilla, Bertiller et al. 1991).

State IV: Recently burned; perennial grasses dominate. Low cover of resprouting shrubs. As State II, it is a transient State.

Transitions:

T 1: Continuous grazing; conditions favorable for shrub seedlings establishment.

T 2: No fire or low fire frequency. A decrease in fire frequency might have favored the increase in quilembai, a very flammable shrub that is severely affected by intense fires.

T 3, T5 \& T 6: Originally, fires set by aborigines or by lightning. At present, most fires are accidentals. Livestock removal or low stocking rates and above-average rainfall through the winter and spring to allow fine fuel accumulation. The postulated change from State IV to State I assumes that fire (T 6) can kill many of the resprouting shrubs, and that the recovering of shrubs by seeds takes a much longer time.

$\mathrm{T} 4$ : Inevitable as shrubs attain maturity. The change in the soil physical characteristics associated to mound formation may favor this transition. Depending on fire intensity ( $\mathrm{T} 3$ ) and postfire conditions (rainfall, grazing), $\mathrm{T} 4$ may take from 10 to 20 years.

Figure 5. A qualitative state-and-transition model for the rangelands of the southern portion of the Monte region, Chubut, Argentina.

could be used as a measure of the beneficial effects of burning and the potential of fire to promote an alternative and persistent state dominated by grasses. The transition from the recently burned, grass-dominated state ( $\mathrm{T} 4$ in Fig. 5) back to the prefire conditions will depend on the shrub regeneration mechanisms, i.e., germination from surviving seed banks or seed arriving from neighboring populations or from sprouting. In a long-term study, West and Yorks (2002) found that in a burned and ungrazed sagebrush semidesert plant community, shrub reinvasion was unexpectedly slow $(<5 \%$ of shrub cover in the burned as compared to $20 \%$ in preburn community). In that community, the dominant shrub, Wyoming big sagebrush (Artemisia tridentata Nutt. Ssp. wyomingensis Beetle \& Young), was re-established through seed dispersal. In our study sites, most shrubs have the ability to regenerate through sprouting and their rate of recovery depended on a combination of species tolerance to fire and the intensity of the different fires. Thus, the rapid recovery of C. avellanedae at site 1 as compared to site 2 may in part be attributed to the more intense fire that affected site 2 (Dentoni et al. 2001). At this site, the fire occurred during the summer, under conditions of high temperature, low humidity, and strong winds. Furthermore, shrub cover and biomass were much greater at this site than at site 1 . Given the positive relationship between fuel load and fire intensity, the high concentration of litter and biomass in the shrub clumps may have increased mortality of C. avellanedae. The canopy of this species is comprised of numerous small branches with a finely divided branching pattern that maximizes surface:volume ratio, allowing for a rapid combustion. At site 2, large individuals of $C$. avellanedae are associated with mounds, on top of which a high amount of litter accumulates (Rostagno et al. 1991). Observations made immediately after the fire indicated that the litter present under the shrubs was almost totally burned, and this might have increased the fire intensity in those patches.

Chuquiraga avellanedae has been characterised as a driver species (Walker 1992; Beeskow et al. 1995) because it has strong ecological functions such as trapping splashed and windblown sediments and litter, favoring the formation of fertility islands and generating a strong contrast between the soils under and among the shrubs. This contrasting pattern in soil resources may contribute to the perpetuation of shrub dominance. By increasing the amount of water percolating to deeper soil horizons, the more permeable soil beneath the shrub 
canopies benefits C. avellanedae and L. divaricata, both species with deep root systems (Bertiller et al. 1991). Fire tends to disrupt this pattern of mounds-intermounds areas associated with shrub-dominated communities, because in the burned areas soil erosion increased dramatically immediately after the fire, affecting mainly the exposed mounds (Rostagno 1999).

At site 1, grasses will probably recede to prefire levels in less than 2 decades as C. avellanedae individuals attain maturity and its cover returns to prefire conditions (transition T 4 in Fig. 5 ). At site 2 , the low cover and density of C. avellanedae recorded 6 years after the fire may favor a more persistent (though not permanent) grass-dominated state. Nevertheless, repeated fires can be necessary to effectively suppress woody plants and favor a more persistent state dominated by perennial grasses. Although the grass-dominated state may not represent a true alternative state, its dynamics and management may be similar. In this case, fire can cause the system to persist in a slowly changing, grass-dominated unstable state (Walker 1988). Data from the burned area at site 3, burned 1 year before sampling indicate that, with adequate rainfall and no livestock grazing, grass cover and biomass can recover to preburn levels and meet the conditions for fire to spread within 2 years. This would support the hypothesis that fire played an important role in controlling the structure and function of the rangelands in the southern portion of the Monte region.

\section{Implications of Fire for Livestock Production}

The relationships between woody and herbaceous plants are of great importance for livestock production and for wildlife conservation. In northern Patagonian rangelands, dominant shrubs (i.e., quilembai and jarilla) make a limited contribution to domestic as well as wildlife herbivore diets. Although there are no reference areas to compare the present status of these rangelands (i.e., areas that have never been under sheep grazing) the original communities probably consisted of grass steppes with scattered shrubs (a physiognomy common 20-30 km east of site 1 , where similar soils dominate). It is probable that, prior to the introduction of the sheep grazing, periodic natural fires would have temporarily reduced shrub dominance. The description of Claraz (1988) during his journey through northern Patagonia from 1865 to 1866 , reporting that various zones had been affected by fires, may indicate a more important role of fire in modeling these communities previous to the European settlement in these lands and the introduction of domestic animals. With the introduction of sheep grazing, a major change in fire frequency most probably occurred, preventing perennial grasses from dominating. Though grasses are more resilient to fire than to continuous grazing, no expertise using prescribed fire as a management tool to control shrubs has been developed in Patagonia. In the study areas, perennial grasses are the most significant diet component for livestock as well as for guanaco (Baldi et al. 2001), and without periodical fires, the cover and biomass of grasses can be severely reduced.

\section{CONCLUSIONS}

Grazing combined with variable rainfall makes the prediction of vegetation changes following fires difficult. However, it can be generally concluded that fire reduced the abundance (cover and density) of most shrub species, and increased the cover and biomass of grasses. This change has persisted for more than 10 years postfire. For this state to be maintained, frequent fires seem to be necessary in order to control the sprouting shrubs and to favor the dominance of perennial grasses. With adequate rainfall and no livestock grazing, grass recovery to support fire spread will occur in 2 to 3 years.

From the perspective of sheep raising, the significant increase in perennial grass biomass and the decrease in cover of unpalatable shrubs represent an improvement of the utilization of these rangelands. Shrubs important in the sheep diet, such as $J$. ligustrina and L. chilense, as well as P. globosum, one of the few legumes present in these rangelands, seem to recover shortly after fire. For guanaco, the only large, native herbivore, grasses of the genuses Stipa and Poa are the most important dietary components, and an increase in grass biomass, keeping large tracts of shrub-dominated areas for refugee, may represent an improvement in its habitat quality.

\section{LITERATURE CITED}

Ares, J., A. M. Beeskow, M. Bertiller, C. M. Rostagno, M. Irisarri, J. Anchorena, G. Defossé, And C. Merino. 1990. Structural and dynamic characteristics of overgrazed lands of northern Patagonia, Argentina. In: A. Breymeyer [ED.]. Managed grasslands: Regional studies. Amsterdam, Netherlands: Elsevier. p 149-75.

Archer, S., D. S. Schimel, and E. A. Holland. 1995. Mechanisms of shrubland expansion: land use, climate or $\mathrm{CO}_{2}$ ? Climate Change 29:91-100.

Baldi, R., S. D. Albon, and D. A. Elston. 2001. Guanacos and sheep: evidence for continuing competition in arid Patagonia. Oecologia 129:561-570.

Beeskow, A. M., N. O. Elissalde, and C. M. Rostagno. 1995. Ecosystem changes associated with grazing intensity on the Punta Ninfas rangelands of Patagonia, Argentina. Journal of Range Management 48:517-522.

Bertiller, M. B., A. M. Beeskow, and F. Coronato. 1991. Seasonal enviromental variation and plant phenology in arid Patagonia (Argentina). Journal of Arid Environment 21:1-11.

Bestelmeyer, B. T., J. E. Herrick, J. R. Brown, D. A. Trujlllo, and K. M. Havstad. 2004. Land management in the American Southwest: a state-and-transition approach to ecosystem complexity. Environmental Management 34:38-51.

Bisigato, A., And M. B. Bertiller. 1999. Seedling emergence and survival in contrasting soil microsites in Patagonian Monte shrubland. Journal of Vegetation Science 10:335-342.

Bóo, R. M., D. V. Peláez, S. C. Bunting, O. R. Elía, and M. Mayor. 1996. Effect of fire on grasses in central semi-arid Argentina. Journal of Arid Environments 32:259-269.

Bóo, R. M., D. V. Peláez, S. C. Bunting, M. Mayor, and O. R. Elía. 1997. Effect of fire on woody species in central semi-arid Argentina. Journal of Arid Environments 35:87-94.

Briske, D. D., S. D. Funlendorf, and F. E. Smeins. 2003. Vegetation dynamics on rangelands: a critique of the current paradigm. Journal of Applied Ecology 40:601-614.

Briske, D. D., S. D. Fuhlendorf, and F. E. Smeins. 2005. State-and-transitions models, thresholds, and rangeland health: A synthesis of ecological concepts and perspectives. Rangeland Ecology and Management 58:1-10.

Claraz, J. E. 1988. Diario de Viaje de Exploración al Chubut 1865-1866. Buenos Aires, Argentina: Marymar Ediciones. 189 p.

COOK, J. G., T. J. Hershey, AND L. L. IRWIN. 1994. Vegetative response to burning on Wyoming mountain-shrub big game ranges. Journal of Range Management 47:296-302.

Dentoni, M., G. Defossé, J. Labraga, and H. del Valle. 2001. Atmospheric and fuel conditions related to the Puerto Madryn fire of 21 January, 1994. Journal of Meteorological Applications 8:361-370. 
Elissalde, N., J. M. Escobar, and V. Nakamatsu. 2002. Inventario y evaluación de pastizales naturales de la zona árida y semiárida de la Patagonia. Trelew, Chubut, Argentina: Programa de Acción Nacional de Lucha contra la Desertificación, SDSyPA-INTA-GTZ. 45 p.

Guevara, J. C., C. R. Stasi, C. F. Wuilloud, and 0. R. Estevez. 2001. Effects of fire on rangeland vegetation in southwestern Mendoza plains, Argentina: composition, frequency, biomass, productivity and carrying capacity. Journal of Arid Environments 41:27-35.

Hodgkinson, K. C., And G. N. HarRington. 1985. The case for prescribed burning to control shrubs in eastern semi-arid woodlands. The Australian Rangeland Journal 7:64-74.

Laycok, W. A. 1991. Stable states and thresholds of range condition on North American rangelands: a viewpoint. Journal of Range Management 44:427-433.

McPherson, G. R. 1995. The role of fire in the desert grassland. In: M. P. McClaran and T. R. Van Devender [EDs.]. The desert grassland. Tucson, AZ: The University of Arizona Press. p 131-151.

Owens, M. K., J. W. Mackley, and C. J. Carrol. 2002. Vegetation dynamics following seasonal fires in mixed mesquite/acacia savannas. Journal of Range Management 55:509-516.

Parizek, B., C. M. Rostagno, and R. Sottinı. (2002). Soil erosion as affected by shrub encroachment in northeastern Patagonia. Journal of Range Management 55:43-49.

Peláez, D. V., R. M. Bóo, O. R. Elía, and M. Mayor. 2003. Effect of fire on growth of three perennial grasses from central semi-arid Argentina. Journal of Arid Environments 55:657-673.

Peterson, G, C. R. Allen, and C. Holling. 1998. Ecological resilience, biodiversity, and scale. Ecosystems 1:6-18.

Pfeiffer, K. E., and A. A. Steuter. 1994. Preliminary response of sand-hills prairie to fire and bison grazing. Journal of Range Management 47:395-397.

Rodriguez, N. F., and P. Cwielong. 1992. Incendios forestales en la Pcia. de Chubut. Análisis expeditivo de pérdidas en los últimos diez años. Esquel, Chubut. Argentina: CIEFAP Internal Report. $12 \mathrm{p}$.

Rostagno, C. M. 1999. La erosión eólica en un área quemada del NE de Chubut. Tucumán, Argentina: Actas XIX Reunión Argentina de Ecología. p 49.

Rostagno, C. M., and H. F. del Valle. 1988. Mounds associated with shrubs in aridic soils of northeastern Patagonia: characteristics and probable genesis. Catena 15:347-359.

Rostagno, C. M., H. F. del Valle, and L. S. Videla. 1991. The influence of shrubs on some chemical and physical properties of an aridic soil in north-eastern Patagonia, Argentina. Journal of Arid Environments 20:179-188.
Scholes, R. J., And S. R. Archer. 1997. Tree-grass interactions in savannas. Annual Review of Ecology and Systematics 28:517-544.

Smith, D. A., AND E. M. Schmutz. 1975. Vegetative changes on protected versus grazed desert grassland ranges in Arizona. Journal of Range Management 28:453-458.

Soriano, A. 1950. La vegetación del Chubut. Revista Argentina de Agronomía 17: $30-66$.

Soriano, A. 1983. Deserts and semideserts of Patagonia. In: N. E. West [ed.]. Temperate deserts and semideserts. Ámsterdam, Netherlands: Elsevier. p 423-460.

SPSS [COMPUTER Program]. 1997. Advanced Statistics 7.5. Chicago, IL: SPSS.

Van Auken, O. W. 2000. Shrub invasion of semiarid grasslands. Annual Review Ecology and Systematics 31:197-215.

Van Langevelde, F., C. van de Vijver, L. Kumar, J. van de Koppel, N. de Ridder, J. van Andel, A. Skidmore, J. Hearne, L. Stroosnijder, W. Bond, H. Prins, and M. RIETKER. 2003. Effects of fire and herbivory on the stability of savanna ecosystems. Ecology 84:337-350.

WalKER, B. H. 1988. Autoecology, synecology, climate and livestock as agents of rangelands dynamics. Australian Rangeland Journal 10:69-75.

WALKER, B. H. 1992. Biodiversity and ecological redundancy. Conservation Biology 6:18-23.

Wambolt, C. L., and G. F. Payne. 1986. An 18-year comparison of control methods for Wyoming big sagebrush in southwestern Montana. Journal of Range Management 39:314-319.

Wambolt, C. L., K. S. Walhof, and M. R. Frisina. 2001. Recovery of big sagebrush communities after burning in south-western Montana. Journal Environmental Management 61:243-252.

West, N. E., and J. HaSsan. 1985. Recovery of sagebrush-grass vegetation following wildfire. Journal of Range Management 38:131-134.

West, N. E., F. D. Provenza, P. S. Johnson, and M. K. Owens. 1984. Vegetation change after 13 years of livestock grazing exclusion on sagebrush semidesert in central Utah. Journal of Range Management 37:262-264.

WEST, N., AND T. YORKS. 2002. Vegetation responses following wildfire on grazed and ungrazed sagebrush semi-desert. Journal of Range Management 55:171-181.

WESTER, D. 1992. Viewpoint: replication, randomization, and statistics in range research. Journal of Range Management 45:285-290.

Westoby, M., B. H. Walker, And I. Noy-MelR. 1989. Opportunistic management for rangelands not at equilibrium. Journal of Range Management 42:266-274.

WilLaRD, E. 1973. Effect of wildfires on woody species in the Monte region of Argentina. Journal of Range Management 26:97-100. 